\title{
Organochlorine Pesticide Residues in Laboratory Animal Foods
}

\author{
Fujio SEKIGUCHI, Haruka MORITA, Takeshi AKIMOTO \\ and Yasuo OSHIMA \\ Research Institute, Daiichi Seiyaku Co. Ltd., \\ 2810, Minamifunabori-cho, Edogawa-ku, Tokyo, Japan
}

(Received for publication: July 2, 1974)

\begin{abstract}
The organochlorine pesticide residue in diet for laboratory animals was quantitatively determined by gas chromatography with acetone and $\mathrm{n}$-hexane extracts. The total level in the diet for mice and rats was $0.243 \mathrm{ppm}$ when determined in June, 1970 and 0.044 ppm in June, 1973. Of the pesticides detected in the diet, $\alpha$-BHC level greatly varied depending upon years, being 0.081 to $0.141 \mathrm{ppm}$ in June, 1970 and $0.009 \mathrm{ppm}$ in June, 1971, while $\beta$-and $\gamma$-BHC levels showed little changes. The $\mathrm{pp}^{\prime}$ DDT level was much lower in 1973 than in from 1970 to 1972. No or only little aldrin and endrin were detected throughout the period of investigation (1970-1973). Similar results were obtained also with the diet for dogs, rabbits, monkeys and chicks. The level of total organochlorine pesticide was detected higher in wheat bran $(0.317 \mathrm{ppm})$ and fish meal $(0.103 \mathrm{ppm})$ than in other ingredients of the animal diet $(0.004-0.027 \mathrm{ppm})$. - Exp. Animals, 24, (1) 13-18, 1975
\end{abstract}

実験動物用固型飼料中に和ける農薬 (BHC, DDT, ドリン剤) の残留について 関口富士男, 森田 遥, 秋元 健, 大身 康夫

第一製薬株式会社研究所

戦後, 開発された有機塩素系農薬 (BHC, DDT，ア ルドリン，ディルドリンおよびェンドリン）は，そのす ぐれた病害虫防除効果により，農産物増収の面で多大の 貢献をしてきた $[5,18]$ 。しかし，てれらの農薬は，土 滾中での残留期間が非常に長いため環境を污染し，作物 を通して動物体内に取り込まれやすい性質がある。ま た，体内ではきわめて分解され難く，脂肪組織などに蓄 積される[14]。

DDT が使用されはじめて数年後の1948年に人体中の DDT 蓄積性が指摘されて以来[19]，野生動物から人間 にいたる多くの動物種について，体内における農薬の残 留調査例が報告されている[19]。乙れと平行して農産物 および畜産物などの食品中の残留農薬についても数多く の報告がなされてきた $[2,11,15]$ 。現在では諸外国にお いて，てれら農薬の使用にはきびしい規制措 置が とら
れ，わが国であ DDT および BHC の販売および使用の 禁止, ドリン系農薬の使用規制措置がとられている。

しかし，土㙵中の農薬は10年という長期間を経てあな お，かなり残留し作物への移行が続くという実験報告が あり[14]，このととは上記の農薬が使用禁止になった現 在でも, 自然界を污染した農薬が食物を通じて, 動物体 内へ移行蓄積されている可能性をうらずけるあのであ る。

農薬の毒性に関する動物実験は, 多くの研究者により 急性，亜急性または慢性毒性 $[1,7,8,12]$ および代謝 [3， 10,13,14]についてなされているが，いずれあ飼料中の 農薬残留量に比べれば，きわめて大量の農薬を強制投与 した実験であり，作物中に含まれる程度の微量農薬の長 期摄取を考慮した報告はみられない。

市販されている実験動物用固型飼料の原料は，小麦， 
フスマ, トウモロコシ, 大豆, ルーサンミール, 脱脂粉 乳，魚粉などが主として使用されているが，てれらの原 料中の残留農薬が実験動物に移行, 蓄積されている濃 度, あるいはてのような動物による各種の長期実験に及 ぼす影響などについて解明されねばならない。そてで， われわれはこれらの諸点を考虑し, まず各種実験動物用 固型飼料中の有機塩素系農薬残留量について調査をてて ろみた。すなわち, マウス・ラット用固型飼料 (4 力年 間), ウサギ・モルモット用, イヌ用, サル用各固型飼 料, 幼雊用飼料 ( 1 力年間) および原料中の農薬残留量 をいずれあガスクロマトグラフィーにより定量したの で，その成績を報告する。

\section{材料および方法}

\section{1. 実験材料}

1）実験動物用固型飼料：1970年 6 月から1973年 6 月 までの 4 カ年間に市販されたマウス・ラット用固型 飼料と，1973年に市販されたウサギ・モルモット用 固型飼料 ( 3 社), イヌ用固型飼料 ( 3 社), サル用 飼料（1 社）および初生雛用配合飼料（1 社）であ る。

2）固型飼料用各種原料：1973年 7 月に入手した小麦 粉, トゥモロコシ, 大豆粕, 魚粉, フスマ, 脱脂棣, 脱脂粉乳およびイーストの 8 原料である。

2. 测定方法

1） ガスクロマトグラフィー

機 種: Shimadzu GC-4APFE (ECD. ${ }^{3} \mathrm{H}$ ) カラム : $\phi 3 \mathrm{~mm} \times 1.1 \mathrm{~m}, \times 2.3 \mathrm{~m}$
充填剤: $1.5 \%$ Silicone OV-17+1.95\% Silicone DC. $\mathrm{QF}-1$

カラム温度 : $190^{\circ} \mathrm{C}$

検出器温度 : $210^{\circ} \mathrm{C}$

2) 試薬

（1）溶媒：市販の残留農薬分析用溶媒をそのまま使 用

(2) カラムクロマトグラフィ一用合成ケイ酸マグネ シウム: Floridin 社製フロリジール

（3）硫酸ナトリウム（無水）：試薬特級品

（4）標準有機塩素系農薬：東京化成工業 K Kの標準 品

3）実験操作 $[2,4,9,17]$

細砕した飼料 $100 \mathrm{~g}$ に，ベンゼン $100 \mathrm{ml}$ を加えて軽 くゆり動かした後，アセトン $100 \mathrm{ml}$ を加えて10分間 激しく振盪して脂肪を抽出した。抽出溶媒をグラスフ ィルターでろ過し, 再び残渣に溶媒を加え, 上記と同 様の操作を 3 回くり返した後, ろ過溶媒を合わせる。 てれに適量の無水硫酸ナトリウムを加え, ときどき 振擝混合させながら約 1 時間放置してろ 過, ついで Kuderna-Danish 型濃縮器を用いて，乃過溶媒を $20 \mathrm{ml}$ に濃縮した。ガラスカラムに活性化したフロリジール を $\mathrm{n}$ ーヘキサンで充填し，その上に無水硫酸ナトリウム を加え, これに上記の濃縮液を正確に $5 \mathrm{ml}$ 注加後, 最初に $6 \%$ エチルエーテル含有 $\mathrm{n}$-ヘキサンを $100 \mathrm{ml}$, ついで15\%エチルエーテル含有 $\mathrm{n}$-ヘキサン $100 \mathrm{ml}$ で 溶出した。溶出液を $5 \mathrm{ml}$ に濃縮して, ガスクロマト グラフィー用検液とした。

定量は, BHC については内部標準物質による方法

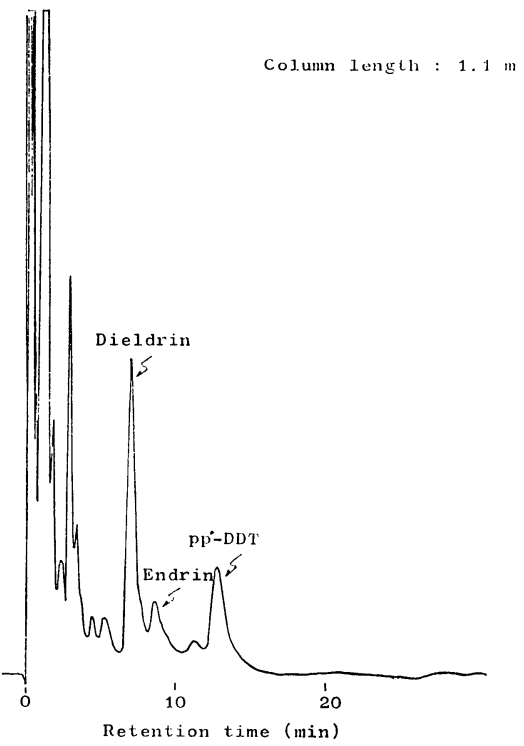

Fig. 1 Gas chromatograms of organochlorine pesticides in laboratory animal diets. 
デイルドリン，エンドリンおよび DDT については波

高法による絶対検量線法に従った。

4）ガスクロマトグラム扔よび回収率

固型飼料中より抽出した有機塩素系農薬についての ガスクロマトグラフィーの結果を, Fig. 1 亿例示し た。また固型飼料中に各種有機塩素系農薬をそれぞれ $0.05 \mathrm{ppm}$ 添加した後, 本法による回収実験の結果を に示した。

Table 1 Recovery rate from diets supplemented with organochlorine pesticide.

\begin{tabular}{cc}
\hline Pesticide & Recovery rate $(\%)$ \\
\hline$\alpha-\mathrm{BHC}$ & 88.9 \\
$\beta-\mathrm{BHC}$ & 70.5 \\
$\gamma$-BHC & 84.3 \\
$\mathrm{pp}^{\prime}-\mathrm{DDT}$ & 78.4 \\
Aldrin & 96.2 \\
Dieldrin & 95.0 \\
Endrin & 90.5 \\
\hline
\end{tabular}

回収実験では， $\beta-B H C$ の収収率が70.5\%とやや低 い值を示したが，その他の農薬については，ほぼ80\% 以上の回収率を得た。

食品中の有機塩素系農薬残留量の測定法については 多数の報告があるが， ECD (Electron Capture Detector）を使用する本法が，農薬の分離定量に適す るあのとされている $[4,9,17]$ 。すなわち，乙の実験の 回収結果より本法は固型飼料中の残留農薬の定量に充 分供しうることが確認されたので, 以後の実験には本 法による分析法を採用した。
成 績

1. マウス・ラット用固型飼料中の有機塩素系農薬の残 留量

固型飼料メーカー 2 社から，1970年 6 月より 1973年 6 月までの 4 年間に市販されたマウス・ラット用固型飼料 中の有機塩素系農薬の残留量を定量した結果を Table 2 および Fig. 2,3 に示した。

$\mathrm{A}$ 社製固型飼料中の総農薬残留 量は，1970年 6 月に $0.243 \mathrm{ppm}$ であったあのが，年々減少傾向を示し，1972 年 6 月には $0.124 \mathrm{ppm}$ で約 $1 / 2$ に減少した。さらに1973年 6 月には 0.044ppm で，1970年度に比較して 3 力年間で 約 $1 / 6$ に減少した。例数は少ないが B 社製品でも，ほぼ同 様の傾向を示した。

BHC異性体については， $\alpha-\mathrm{BHC} 1970$ 年 6 月に0.081 ppmであったものが， 1 年後には 0.009ppm と，かなり 激減した。しかし $\beta-\mathrm{BHC}$ および $\gamma-\mathrm{BHC}$ は，1970年か らの 3 力年間ではほとんど減少していなかった。

$\mathrm{pp}^{\prime}-\mathrm{DDT}$ については，1970年 6 月に $0.091 \mathrm{ppm}$ であ ったあのが 7 年後には $0.040 \mathrm{ppm}$ となり, 以後しだいに 減少傾向を示した。

デイルドリンは，1970年から1973年までの間 0.038〜 $0.008 \mathrm{ppm}$ の範囲で, 製造年度により多少の変動はみら れるが，ほとんど減少傾向を示さなかった。

エンドリンは，ほとんど検出されず，またアルドリン は，まったく検出されなかった。

2. イヌ, ウサギ・モルモット, サル, 幼雊用飼料中の 有機塩素系農薬の残留量

1972年から1973年に市販された各種動物用飼料中の有

Table 2 Organochlorine pesticide residue in the diets for mice and rats purchased between June 1970 and June 1973.

(ppm on whole basis)

\begin{tabular}{|c|c|c|c|c|c|c|c|c|c|c|c|}
\hline \multicolumn{2}{|c|}{$\begin{array}{l}\text { Time of } \\
\text { purchase }\end{array}$} & Maker & $\alpha-\mathrm{BHC}$ & $\beta-\mathrm{BHC}$ & $\gamma-\mathrm{BHC}$ & $\begin{array}{l}\text { Total } \\
\text { BHC }\end{array}$ & $\mathrm{pp}^{\prime}-\mathrm{DDT}$ & Aldrin & Dieldrin & Endrin & $\begin{array}{c}\text { Total } \\
\text { Pesticides }\end{array}$ \\
\hline Jun. & 1970 & $\begin{array}{l}\mathrm{A} \\
\mathrm{B}\end{array}$ & $\begin{array}{l}0.081 \\
0.141\end{array}$ & $\begin{array}{l}0.006 \\
0.035\end{array}$ & $\begin{array}{l}0.022 \\
0.040\end{array}$ & $\begin{array}{l}0.109 \\
0.216\end{array}$ & $\begin{array}{l}0.091 \\
0.046\end{array}$ & $\begin{array}{l}\text { nd } \\
\text { nd }\end{array}$ & $\begin{array}{l}0.038 \\
0.046\end{array}$ & $\begin{array}{l}0.005 \\
0.003\end{array}$ & $\begin{array}{l}0.243 \\
0.310\end{array}$ \\
\hline Jun. & 1971 & A & 0.009 & 0.025 & 0.041 & 0.075 & 0.040 & nd & 0.039 & 0.001 & 0.155 \\
\hline Sep. & 1971 & A & 0.011 & 0.005 & 0.044 & 0.060 & 0.042 & nd & 0.013 & $\operatorname{tr}$ & 0.173 \\
\hline Jun. & 1972 & $\begin{array}{l}\mathrm{A} \\
\mathrm{B}\end{array}$ & $\begin{array}{l}0.009 \\
0.085\end{array}$ & $\begin{array}{l}0.015 \\
0.006\end{array}$ & $\begin{array}{l}0.022 \\
0.005\end{array}$ & $\begin{array}{l}0.046 \\
0.103\end{array}$ & $\begin{array}{l}0.043 \\
0.031\end{array}$ & $\begin{array}{l}\text { nd } \\
\text { nd }\end{array}$ & $\begin{array}{l}0.035 \\
0.044\end{array}$ & $\begin{array}{c}\operatorname{tr} \\
0.001\end{array}$ & $\begin{array}{l}0.124 \\
0.179\end{array}$ \\
\hline Oct. & 1972 & A & 0.012 & 0.005 & 0.018 & 0.035 & 0.035 & nd & 0.013 & nd & 0.083 \\
\hline Nov. & 1972 & A & 0.008 & 0.015 & 0.023 & 0.046 & 0.024 & nd & 0.016 & nd & 0.086 \\
\hline Feb. & 1973 & $\begin{array}{l}\text { A } \\
\text { B }\end{array}$ & $\begin{array}{l}0.013 \\
0.003\end{array}$ & $\begin{array}{l}0.023 \\
0.003\end{array}$ & $\begin{array}{l}0.012 \\
0.005\end{array}$ & $\begin{array}{l}0.059 \\
0.011\end{array}$ & $\begin{array}{l}0.012 \\
0.007\end{array}$ & $\begin{array}{l}\text { nd } \\
\text { nd }\end{array}$ & $\begin{array}{l}0.029 \\
0.008\end{array}$ & $\begin{array}{c}\text { nd } \\
0.001\end{array}$ & $\begin{array}{l}0.100 \\
0.027\end{array}$ \\
\hline Jun. & 1973 & $\begin{array}{l}\mathrm{A} \\
\mathrm{B}\end{array}$ & $\begin{array}{l}0.010 \\
0.010\end{array}$ & $\begin{array}{l}0.023 \\
0.004\end{array}$ & $\begin{array}{l}0.012 \\
0.032\end{array}$ & $\begin{array}{l}0.059 \\
0.046\end{array}$ & $\begin{array}{l}0.012 \\
0.006\end{array}$ & $\begin{array}{l}\text { nd } \\
\text { nd }\end{array}$ & $\begin{array}{l}0.008 \\
0.021\end{array}$ & $\begin{array}{c}\text { nd } \\
0.004\end{array}$ & $\begin{array}{l}0.044 \\
0.077\end{array}$ \\
\hline
\end{tabular}




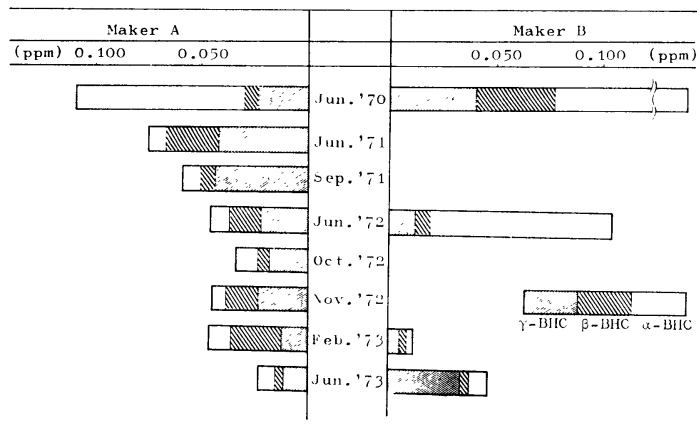

Fig. 2 Changes in pesticide residue in the diets for mice and rats purchased between June 1970 and June 1973.

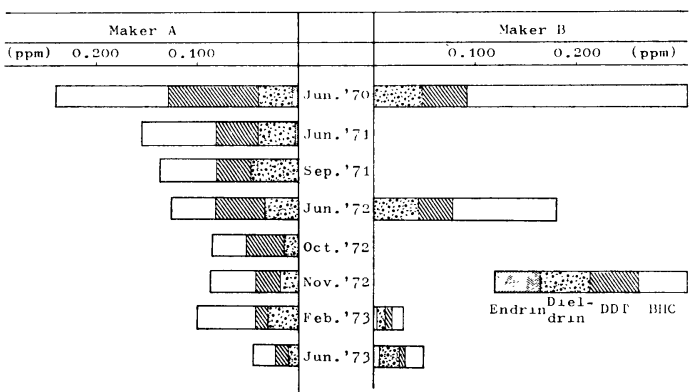

Fig. 3 Changes in BHC isomers in the diets for mice and rats purchased between June 1970 and June 1973.

Table 3 Organochlorine pesticide residue in diets for different laboratory animals purchased between October 1972 and June 1973.

(ppm on whole basis)

\begin{tabular}{lccccccccccc}
\hline \multicolumn{1}{c}{ Diet for } & Maker & $\alpha$-BHC & $\beta$-BHC & $\gamma$-BHC & $\begin{array}{c}\text { Total } \\
\text { BHC }\end{array}$ & $\mathrm{pp}^{\prime}$-DDT & Aldrin & Dieldrin & Endrin & $\begin{array}{c}\text { Total } \\
\text { Pesticides }\end{array}$ \\
Dogs & $\mathrm{A}$ & 0.016 & 0.007 & 0.074 & 0.097 & 0.041 & nd & 0.021 & 0.001 & 0.160 \\
& $\mathrm{~B}$ & 0.003 & 0.004 & 0.021 & 0.028 & 0.010 & nd & 0.003 & nd & 0.041 \\
& $\mathrm{C}$ & 0.008 & 0.010 & 0.028 & 0.046 & 0.010 & nd & 0.020 & 0.002 & 0.078 \\
\hline \multirow{2}{*}{$\begin{array}{l}\text { Rabbits and } \\
\text { Guiea-pigs }\end{array}$} & $\mathrm{A}$ & $\mathbf{B}$ & 0.006 & 0.005 & 0.054 & 0.065 & 0.172 & nd & 0.023 & 0.002 & 0.262 \\
& $\mathrm{C}$ & 0.009 & 0.005 & 0.020 & 0.031 & 0.022 & nd & 0.014 & 0.001 & 0.068 \\
Monkeys & & 0.030 & 0.008 & 0.046 & 0.084 & 0.010 & nd & 0.016 & tr & 0.110 \\
\hline Chicks & & 0.003 & 0.001 & 0.003 & 0.007 & tr & nd & 0.034 & nd & 0.041 \\
\hline
\end{tabular}

機塩素系農薬の残留量を定量した結果を Table 3 に示 した。

ウサギ・モルモット用固型飼料の総農薬残留量につい ては， 3 社製品比較で，やはり $\mathrm{A}$ 社製品の $0.262 \mathrm{ppm}$ が 他の 2 社製品の $0.063 \sim 0.068 \mathrm{ppm}$ に比べて高い值を示 した。また $\mathrm{A}$ 社の飼料中には他の 2 社製品に比べて $\mathrm{pp}^{\prime}-$ DDT がかなり多く残留していた。

サル用飼料および幼雊用配合飼料については，いずれ あ総農薬残留量が $0.110 \sim 0.041 \mathrm{ppm}$ で，他の固型飼料 とほぼ同程度の值を示した。

\section{3. 原料中の有機塩素系農薬の残留量}

実験動物用固型飼料の原料として使用されている小麦 粉，トウモロコシ，大豆粕，魚粉，フスマ, 脱脂糠，脱 脂粉乳およびイーストの 8 原料について有機塩素系農薬 の残留量を定量した結果を Table 4 に示した。

その結果，フスマの総農薬残留量は $0.317 \mathrm{ppm}$ であ り，原料中最高值を示した。ついで魚粉中の総農楽残留 量は $0.103 \mathrm{ppm}$ で，てのうち $\beta-\mathrm{BHC}$ が $0.074 \mathrm{ppm}$ を
占めていた。また脱脂棣中の $\mathrm{pp}^{\prime}-\mathrm{DDT} \quad 0.075 \mathrm{ppm}$ で あり，他の原料に比べ最高値を示した。

一方, 固型飼料中の配合割合の多い小麦粉, トウモロ コシおよび大豆粕中の総農薬残留量は，いずれむ 0.019 $\mathrm{ppm}$ 以下であり， BHC， pp'-DDT，ディルドリンおよ びエンドリンの各農薬む，0.006ppm 以下であった。ア ルドリンはまったく検出されなかった。

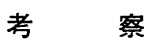

実験動物用各種固型飼料中の有機塩素系農薬の残留量 を定量した結果， $\mathrm{BHC}$ が最も多く，ついで $\mathrm{pp}^{\prime}-\mathrm{DDT}$, デイルドリンの順に低減し，エンドリンおよびアルドリ ンはほとんど検出されなかった。

マウス・ラット用固型飼料中の年次別の総農薬残留量 は，1970年に 0.243〜0.310ppm であったあのが， 4 年 後の1973年には $0.044 \sim 0.077 \mathrm{ppm}$ に減少した。これは 1969年から1971年にかけて日本および諸外国における有 
Table 4 Organochlorine pesticide residue in different ingredients of laboratory animal diets purchased in July 1973.

(ppm on whole basis)

\begin{tabular}{lcccccccccc}
\hline \multicolumn{1}{c}{ Ingredient } & $\alpha-\mathrm{BHC}$ & $\beta-\mathrm{BHC}$ & $\gamma$-BHC & $\begin{array}{c}\text { Total } \\
\text { BHC }\end{array}$ & $\mathrm{pp}^{\prime}$-DDT & Aldrin & Dieldrin & Endrin & $\begin{array}{c}\text { Total } \\
\text { Pesticides }\end{array}$ \\
Wheat flour & 0.002 & 0.001 & 0.002 & 0.005 & 0.003 & nd & 0.003 & nd & 0.011 \\
Corn & 0.001 & 0.001 & 0.002 & 0.004 & nd & nd & nd & nd & 0.004 \\
Defatted soy bean & nd & 0.004 & nd & 0.004 & 0.006 & nd & 0.006 & 0.003 & 0.019 \\
Fish meal & 0.002 & 0.074 & 0.003 & 0.079 & 0.002 & nd & 0.022 & $\operatorname{tr}$ & 0.103 \\
Wheat bran & 0.230 & 0.035 & 0.028 & 0.293 & 0.019 & nd & 0.004 & 0.001 & 0.317 \\
Defatted rice bran & 0.007 & 0.002 & 0.003 & 0.012 & 0.075 & nd & 0.006 & 0.002 & 0.095 \\
Dried skimmilk & $\operatorname{tr}$ & 0.003 & 0.002 & 0.005 & $\operatorname{tr}$ & nd & 0.022 & nd & 0.027 \\
Yeast & 0.002 & 0.001 & 0.002 & 0.005 & 0.002 & nd & 0.004 & nd & 0.011 \\
\hline
\end{tabular}

機塩素系農薬の使用禁止措置による結果と考えられる。 しかし,この種の農薬の自然界污染の現状から考えると， 低濃度での長期残留が推定される。

わが国における固型飼料原料は，その90\%以上を諸外 国からの輸入に依存しているが，各種原料別配合割合で 全体の約 $60 \%$ 占めている小麦粉, トウモロコシおよび 大豆粕の農薬残留量は比較的少ない。しかしフスマでは BHC，とくに $\alpha$-BHCの残留量が多かった。これはこの 実験に使用したフスマが国内産のあのであり，しかもわ が国におりる BHC の使用量が外国に比較して，かなり 多かったととと関連があると推定される[5]。魚粉では $\beta-\mathrm{BHC}$ の残留量が多い成績が得られたが，これは魚粉 が動物性のために $\beta-\mathrm{BHC}$ の生体内蓄積性が高いためで あると考えられる。

すなわち今回の調査で, 他の農薬に比べて BHC 含有 量があっとも多く，その異性体の中でとくに $\beta-\mathrm{BHC}$ 招 よび $\gamma-\mathrm{BHC}$ の減少傾向がゆるやかなととは, 実験動物 への蓄積性と考えあわせ，極めて重視すべき問題と考え る。

BHC は，異性体によりその性質がかなり異なり， $\alpha-$ $\mathrm{BHC}$ は生物体内であまり毒性を示さないが， $\beta-\mathrm{BHC}$ 脂肪組織内蓄積性が高く慢性毒性があっとも強いとされ ている。また $\gamma$-BHC は立体構造がきわめて安定であり 急性毒性は非常に強いが，代謝あ比較的うけやすいもの であるとされている[14]。

DDT およびデイルドリンはとあに減少傾向にあるが とくに DDT は BHC よりも土壤残留期間が長く[11], また体脂中に食餌中残留濃度の 6 ～14倍蓄積されるとい う報告がある[14]。

これらのととを考慮すれば，農薬を含有している飼料 を, 毎日摄飭している実験動物は, 当然農薬の体内蓄皘 が考えられ，乙のような動物を使用しておこなう長期実
験では，残留農薬による影響, とくに偶発病像との関係， または外見上病的な症状変化を示さないが，これにある 外部刺激を与えた時に起る病的な変化など重要な諸問題 を解明しなければならない。

\section{要 約}

1970年から1973年の間に市販されたマウス・ラット用 固型飼料および1973年に市販されたイヌ，ウサギ・モル モット，サル，雛用飼料の有機塩素系農薬 (BHC, DDT, アルドリン，デイルドリンおよびエンドリン）の残留量 をガスクロマトグラフィー (ECD-GC) により定量して つぎの成績をえた。

（1）マウス・ラット用固型飼料中の総農薬残留量は1970 年から1973年に減少傾向を示した。

$\mathrm{BHC}$ 異性体のうち $\alpha-\mathrm{BHC}$ 含量の変化は著明だっ たが, $\beta-\mathrm{BHC}$ および $\gamma-\mathrm{BHC}$ 含量はほとんど変化が なかった。デイルドリン，pp'-DDT はわずかである が減少傾向を示し，アルドリンおよびェンドリンはほ とんど検出されなかった。

（2）イヌ，ウサギ・モルモット，サル，雊用各飼料の総 農薬残留量はマウス・ラット用固型飼料とほぼ同程度 であった。

（3）各種飼料原料 8 品目の総農薬残留量は, 小麦粉, 卜 ウモロコシ，大豆粕，脱脂粉乳に比べ，フスマおよび

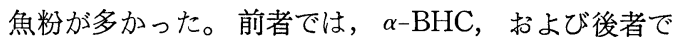
は $\beta-\mathrm{BHC}$ が多く, $\mathrm{pp}^{\prime}-\mathrm{DDT}$ は脱脂棣にもっとも多 かった。

終りに当り, 種々御教示を賜わった残留農薬研究所毒 性部長白須泰彦博士，化学第一研究室長俣野修身博士な らびに終始, 御鞭達下さった第一製薬株式会社研究所長 
古賀直文博士に感謝いたします。

なお本報の概要は日本実験動物研究会第 8 回研究発表 会 (静岡) で発表した。

\section{文献}

[1] Deichmann. Wm. B., Keplinger. M., Dressler. I., Sala. F. (1969). Retention of Dieldrin and DDT in the Tissues of Dogs Fed Aldrin and DDT Individually and as a Mixture. Toxicol. Appl. Pharmacol., 14, 205-213.

[2] 川城㦑・二郷俊郎(1965)：食品中残留農薬につい $\tau$, 食品衛生学雑誌, $6,182-194$

[3] Menzie. C. M. (1969). Metabolism of Pesticides. U. S. Dept. of Inter., 128

[4] Minyard. J. P., Jackson. E. R. (1963). Pesticide Residues in Commercial Animal Feeds. Journal of The A. O. A. C., 46

[5] 日本植物防度協会編 (1970): 農薬要覧

［6]西本孝男 ·上田雅彦・田植栄 (1966)：食品中残留 農薬の研究(IV), 食品衛生学雑誌, 7, 152-162

[7] 大柴恵一・川上兵蔵 (1970)：毒性物質と栄養との 関係(第 1 報), 食品衛生学雑誌, $11,177-180$

[8] 大柴恵一・川上兵蔵(1970：毒性物質と栄養との 関係(第 2 報)，食品衛生学雑誌，11，445-448

[9] Pesticide Analytical Manual (1967). U. S. Department of Health. Education and Welfare. Food and Drug Administration, 1.

[10] Peterson. J. E., Robison. W. H. (1964).
Metabolic Products of $\mathrm{pp}^{\prime}-\mathrm{DDT}$ in the Rat. Toxicol. Appl. Pharmacol., 3, 312.

[11] 使用禁止等措置後に扣ける有機塩素系農薬の土壤 残留性およびその農作物におよぼす影響に関する調 査研究 (1972) : 残留農薬研究所

[12] Thrope. E., Walker. A. I. T. (1973). The Toxicolgy of Dieldrin. II. Comparative Longterm Oral Toxicity Studies in Mice with Dieldrin, DDT, Phenobarbitone, $\beta$-BHC and $\gamma-$ BHC, Fd Cosmet. Toxicol., 11, 433-442.

[13] Uchiyama. M. (1973). From the Standpoint of Toxicolgy. Modern Media, 19, 302-310.

[14] 内山充 (1972)：有機塩素剂の動物体内代謝, バイ オテク, $3,26-33$

[15] Ueta. M., Taue. S., Nishimoto. T. (1970). Residues of BHC Isomers and Other Organochlorine Pesticides in Fatty Food of Japan. J. Food Hyg. Soc. Japan, 11, 256-263.

[16] Walker. A. I. T., Thrope. E., Stevenson. D. E. (1972). The Toxicolgy of Dieldrin. II. Longterm Oral Toxicity Studies in Mice. Fd Cosmet. Toxicol., 11, 413-432.

[17] Watts. J. O., Klein. A. K. (1963). Determination of Chlorinated Residues by Electron Capture Gas Chromatography. Journal of The A. O. A. C., 45

[18] 山本亮 (1958)：新農薬研究法, 南江堂

［19］湯嶋健・桐谷圭治・金沢純（1971） 殺虫剂による 生態系の污染IV，科学，41，9，507-519 